\title{
Paclitaxel Vitamin E-Based Emulsion
}

National Cancer Institute

\section{Source}

National Cancer Institute. Paclitaxel Vitamin E-Based Emulsion. NCI Thesaurus. Code C61079.

A cremophor-free, P-glycoprotein-inhibiting, vitamin E-based emulsion particle formulation of paclitaxel with antineoplastic activity. Paclitaxel binds to tubulin and inhibits the disassembly of microtubules, thereby resulting in the inhibition of cell division. This agent also induces apoptosis by binding to and blocking the function of the apoptosis inhibitor protein B-cell Leukemia 2 (Bcl-2). The vitamin-E based emulsion allows bolus infusion without steroid premedication and may diminish hypersensitivity reactions. The tumor tissue may be passively targeted due to preferential deposition of emulsion particles while an emulsion formulation component inhibits the P-glycoprotein drug efflux pump. 